\title{
Spectrophotometric Determination of Chlorpropamide in Bulk and Dosage Form by Complexation with Chloranilic Acid
}

\author{
C. J. Mbah* and N. H. Okorie \\ Department of Pharmaceutical and Medicinal Chemistry, Faculty of Pharmaceutical Sciences, \\ University of Nigeria, Nsukka, Enugu State, Nigeria
}

Received 19 April 2010, accepted in revised form 3 December 2010

\begin{abstract}
A spectrophotometric study of chlorpropamide is described. The method is based on the charge-transfer complexation between chlorpropamide (the $n$-electron donor) with chloranilic acid (the $\pi$-acceptor) to form a violet coloured complex having absorption maxima at $530 \mathrm{~nm}$. Beer's law is obeyed for up to $5-25 \mu \mathrm{g} / \mathrm{ml}$ of chlorpropamide. Results of the analysis of this method were validated statistically by recovery studies. The proposed method is simple, accurate and precise for the quantitative determination of chlorpropamide in bulk and tablet formulations.
\end{abstract}

Keywords: Chlorpropamide; Spectrophotometry; Chloranilic acid.

(c) 2011 JSR Publications. ISSN: 2070-0237 (Print); 2070-0245 (Online). All rights reserved. doi:0.3329/jsr.v3i1.4808

J. Sci. Res. 3 (1), 207-212 (2011)

\section{Introduction}

Chlorpropamide is chemically, 1-[(p-chlorophenyl)sulfonyl]-3-propylurea. Clinically, it is very effective in the treatment diabetes mellitus. Its mechanism of action involves the stimulation of insulin release from the $\beta$-cells of the pancreas in response to a glucose load [1]. It also acts by enhancing the effect of insulin on the liver and promote peripheral glucose utilization by increasing the number of insulin receptors. The United States Pharmacopeia [2] adopts a high performance liquid chromatography (HPLC) for the determination of chlorpropamide. A spectrophotometric method is used by British Pharmacopeia [3]. Literature survey revealed that various methods of analysis for chlorpropamide have been reported which included, titrimetric [4], gas chromatography [5-6] and HPLC [7-9]. Charge-transfer complexes are formed by the interaction between electron donors and electron acceptors [10]. The use of chloranilic acid (2,5-dichloro-3,6dihydroxy-p-benzoquinone) as a $\pi$-acceptor in the spectrophotometric analysis of some organic compounds containing lone pair of electrons has been reported [11-14] but not hitherto in the assay of chlorpropamide. The need for a rapid, economic and sensitive method is required especially for laboratories that cannot afford expensive instruments.

*Corresponding author: cjmbah123@yahoo.com 
The aim of the study therefore, is to develop a simple, fast, sensitive colorimetric method for the assay of chlorpropamide in bulk and pharmaceutical formulations via chargetransfer complexation.

\section{Materials and Method}

\subsection{Materials}

Chlorpropamide (Neimeth International Pharmaceutical, Nigeria), all other chemicals were of analytical grade. Freshly prepared $0.5 \%$ (w/v) chloranilic acid solution in dioxan.

\subsection{Apparatus}

A Hitachi UV/VIS spectrophotometer, model 2000 (Japan) was used for absorbance measurements.

\subsection{Standard solution}

A stock solution of chlorpropamide (50 $\mu \mathrm{g} / \mathrm{ml})$ was prepared by dissolving the required amount in ethanol. Standard solutions of the analyte $(5-25 \mu \mathrm{g} / \mathrm{ml})$ were prepared by serial dilution of the stock solution.

\subsection{Proposed procedure}

An aliquot $(1.0 \mathrm{ml})$ of the standard solution containing chlorpropamide was transferred into a $10 \mathrm{ml}$ volumetric flask. A 1-ml volume of chloranilic acid solution $(500 \mu \mathrm{g} / \mathrm{ml})$ was added and the contents were mixed thoroughly. After 30 min standing, the volume was made up with dioxan and the absorbance of the solution was measured at $530 \mathrm{~nm}$ against reagent blank. Optical characteristic and statistical data for the regression equation of the proposed method are shown in Table 1.

Table 1. Optical characteristic and statistical data for the regression equation of the proposed method*

\begin{tabular}{ll}
\hline Parameter & Value \\
\hline$\lambda_{\max }(\mathrm{nm})$ & 530 \\
Beer's law range $\left(\mu \mathrm{g} \mathrm{ml}^{-1}\right)$ & $5-30$ \\
Molar absorptivity $\left(\mathrm{l} \mathrm{mol}^{-1} \mathrm{~cm}^{-1}\right)$ & $1.2073 \times 10^{4}$ \\
Colour stability (hours) & 2 \\
Regression equation & \\
Slope & 0.0424 \\
Intercept & 0.0100 \\
Correlation coefficient $(r)$ & 0.9998 \\
\hline
\end{tabular}

\% Relative standard deviation $(n=5)=1.2$, $Y^{*}=a+b C$, where $C$ is the concentration in $\mu \mathrm{g} \mathrm{ml}^{-1}$. 


\subsection{Procedure for assay of dosage forms}

Ten tablets of the drug were weighed and ground to a fine powder. An adequate amount of the powder was transferred into a beaker. The powder was dissolved in ethanol by stirring for $15 \mathrm{~min}$. The mixture was filtered to a volumetric flask (100 ml) through Whatman filter paper No. 41. The filtrate and washings were diluted to volume with ethanol. A suitable volume of this solution was treated as described under proposed procedure and the drug content was evaluated. The results are given in Table 2.

Table 2. Determination of chlorpropamide in formulations by the proposed method.

\begin{tabular}{|c|c|c|c|}
\hline \multirow{2}{*}{$\begin{array}{c}\text { Volume (ml) of } \\
\begin{array}{c}\text { chlorpropamide } \\
\text { solution }\end{array}\end{array}$} & \multicolumn{2}{|c|}{ Amount ( $\mu \mathrm{g}$ ) of } & \multirow{2}{*}{$\begin{array}{c}\text { Recovery } \\
(\%)\end{array}$} \\
\hline & $\begin{array}{l}\text { chlorpropamide } \\
\text { present }\end{array}$ & $\begin{array}{c}\text { chlorpropamide } \\
\text { found }\end{array}$ & \\
\hline 0.2 & 5.0 & 4.9983 & 99.92 \\
\hline 0.4 & 10.0 & 10.0334 & 100.33 \\
\hline 0.6 & 15.0 & 15.2105 & 101.40 \\
\hline 0.8 & 20.0 & 20.0435 & 100.21 \\
\hline \multirow[t]{2}{*}{1.0} & 25.0 & 25.2062 & 100.82 \\
\hline & \multicolumn{2}{|c|}{ Mean \pm s.d: } & $4 \pm 0.58$ \\
\hline
\end{tabular}

\subsection{Procedure for recovery of chlorpropamide}

To study the recovery of chlorpropamide, samples were prepared by mixing known amounts of pure chlorpropamide with portions of commercial preparation. The mixtures obtained were assayed by proposed method and the results are presented in Table 3.

Table 3. Recovery of chlorpropamide in tablet-pure sample mixture by the proposed method.

\begin{tabular}{cccc}
\hline \multicolumn{3}{c}{ Amount (mg) of } & $\begin{array}{c}\text { Recovery } \\
(\%)\end{array}$ \\
\cline { 1 - 3 } $\begin{array}{c}\text { chlorpropamide } \\
\text { present in tablet }\end{array}$ & $\begin{array}{c}\text { chlorpropamide } \\
\text { added }\end{array}$ & $\begin{array}{c}\text { chlorpropamide } \\
\text { found }\end{array}$ & \\
\hline 250 & 0.0 & 250.2750 & 100.11 \\
250 & 10 & 257.8503 & 99.17 \\
250 & 15 & 265.0743 & 100.03 \\
250 & 20 & 273.1382 & 101.16 \\
250 & 25 & 274.2889 & 99.74 \\
& & Mean \pm s.d & $100.04 \pm 0.73$ \\
\hline
\end{tabular}




\section{Results and Discussion}

\subsection{Spectrophotometric characteristic of the chlorpropamide-chloranilic acid system}

A violet coloured complex with a ratio of chlorpropamide to reagent of 1:1 was formed when chloranilic acid solution was added to chlorpropamide solution. The complex exhibited a $\lambda_{\max }$ at $530 \mathrm{~nm}$ while the reagent showed a $\lambda_{\max }$ at $434 \mathrm{~nm}$. An absorbance of the complex using an aliquot of the standard solution was measured at $530 \mathrm{~nm}$ at $30 \mathrm{~min}$ interval over a period of $2 \mathrm{~h}$. No change in the initial absorbance was observed indicating the stability of the complex. Beer's law was obeyed in the range of $5-25 \mu \mathrm{g} / \mathrm{ml}$. Beer's law range, molar absorptivity, slope, linear least-square analysis are given in Table 1.

\subsection{Optimization of reaction conditions}

\subsubsection{Effect of chloranilic acid concentration}

The effect of chloranilic acid concentration on the colour development was studied. It was observed that $1 \mathrm{ml}$ of $0.5 \%(\mathrm{w} / \mathrm{v})$ chloranilic acid solution produced maximum colour intensity (Fig. 1).

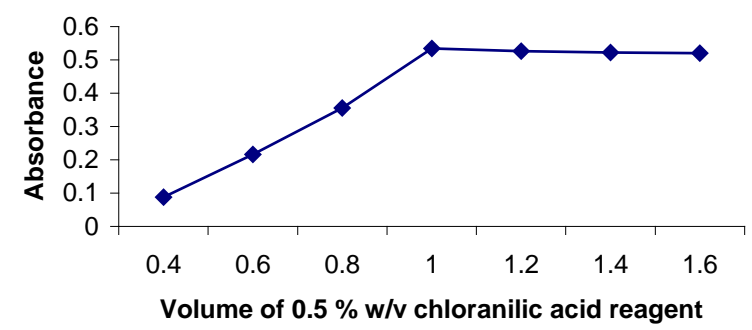

Fig. 1 Effect of chloranilic acid reagent concentration on the development of charge-transfer complex of chlorpropamide at $\lambda=530 \mathrm{~nm}$.

\subsubsection{Effect of reacting time}

The colour product developed rapidly after addition of the reagent attaining maximum intensity after $30 \mathrm{~min}$ at room temperature (Fig. 2). The colour was stable for over $2 \mathrm{~h}$.

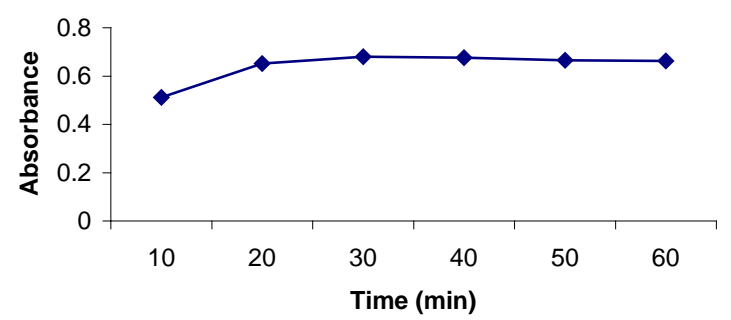

Fig. 2. Effect of time on development of charge-transfer complex of chlorpropamide and chloranilic acid at $\lambda=530 \mathrm{~nm}$. 


\subsection{Stoichiometric relationship}

In order to establish the composition of the charge-transfer complex, the molar ratio method and Job's method of continuous variation using equimolar solutions of the drug $(0.004 \mathrm{M})$ and reagent $(0.004 \mathrm{M})$ were studied. In the molar ratio method, the concentration of the drug was kept constant while varying the concentration of the reagent in the series of solutions prepared. In the Job's method, equimolar solutions of the drug and the reagent were mixed in complimentary proportions to a fixed total volume. The results obtained indicate that the composition of charge-transfer complex was (1:1) drug to reagent (Fig. 3).

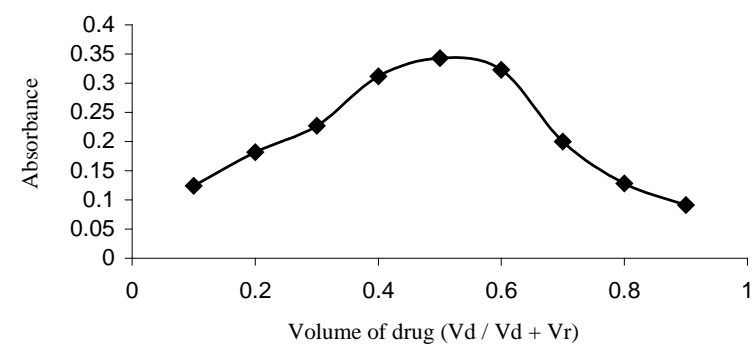

Fig. 3. Continuous variation plot for the charge-transfer complex, $\lambda=530 \mathrm{~nm}$, where $V_{\mathrm{d}}$ and $V_{\mathrm{r}}$ are the volumes of added drug and reagent respectively.

\section{Conclusion}

The described spectrophotometric method was applied in the assay of chlorpropamide in bulk and pharmaceutical formulations. The method is simple, accurate and reproducible. The statistical analysis has good agreement with reported methods. The optimum conditions for the proposed method have been established and the method has shown a reasonable tolerance towards excipients. Finally, the proposed method can be employed for the routine analysis of chlorpropamide from bulk and tablet dosage form in quality control laboratories due to the minimum time required for the complexation to be complete.

\section{References}

1. R. W. Foster, Basic Pharmacology, $3^{\text {rd }}$ Edition (Butterworth Heinemann Ltd., London, 1991) p. 186.

2. The United States Pharmacopeia, $27^{\text {th }}$ Revision (US Pharmacopeial Convention, MD, 2004) $p$. 436.

3. The British Pharmacopeia, Vol. III (Her Majesty Stationary Office, London, 2008) p. 2530.

4. M. G. El-Bardicy, S. Z. El-Khateeb, H. N. Assad, and A. S. Ahmed, Indian J. Pharm. Sci. 50, 171 (1998).

5. S. Khalid and S. Khawla, J. Pharm. Sci. 59, 782 (1970). doi:10.1002/jps.2600590612

6. K. K. Midha, I. A. McGilveray, and C. Charette, J. Pharm. Sci. 65, 576 (1976). 
doi:10.1002/jps.2600650424

7. M. T. Bakare, I. S. Enemali, M. Garba, and O. O. Obodozie, Afri. J. Biotech. 6, 1378 (2007).

8. D. Molins, C. K. Wong, D. M. Cohen, and K. D. Munnelly, J. Pharm. Sci. 64, 123 (1975). doi:10.1002/jps.2600640127

9. D. L. Robertson, A. G Butterfold, H. Kolasinski, and E. G. Lovering, J. Pharm. Sci. 68, 577 (1979). doi:10.1002/jps.2600680516

10. M. A. El-Sayed and S. P. Agarwal, Talanta 29, 535 (1982). doi:10.1016/0039-9140(82)80212-9

11. M. Walash, E. M. Sharaf, M. Meturalli, and M. Redashabara, J. Arch. Pharm. Res. 27, 720 (2007). doi:10.1007/BF02980138

12. A. A. Attama, P. O. Nnamani, M. U. Adikwu, and F. O. Akidi, STP Pharm. Sci. 13, 419 (2003).

13. M. U. Adikwu and K. C. Oforkansi, J. Pharm. Biomed. Anal. 16, 527 (1997). doi:10.1016/S0731-7085(97)00086-1

14. M. A. El-Sayed, M. Barary, M. A. Abdel-Salam, and Y. A Mohamed, Anal. Lett.22, 1651 (1984). 